\section{Tropical Journal of Ophthalmology and Otolaryngology}

\title{
Change to win - flapless external dacryocystorhinostomy (DCR)
}

\section{Ranjan R. ${ }^{1}{ }^{*}$, Rupam K. ${ }^{2}$, Kumar S. $^{3}$}

DOI: https://doi.org/10.17511/jooo.2020.i08.04

1* Ravi Ranjan, Awadh Medicare, Bikramganj, Bihar, India.

2 Kumari Rupam, Consultant, Awadh Medicare, Bikramganj, Bihar, India.

${ }^{3}$ Sudhir Kumar, Associate Professor, Government Medical College, Bettiah, Bihar, India.

Introduction: Nasolacrimal Duct obstruction (NLDO) is a common ophthalmic problem and the usual Treatment is Dacryocystorhinostomy (DCR), either external or endonasal. This study aims to evaluate the success of external DCR with neither anterior nor posterior flaps with Mitomycin $c$ (MMC) syringing on the $5^{\text {th }}$ post-operative day (early proliferative phase of wound healing). It was shown in the present study that a comparable good result can be achieved without tedious flaps making and anastomosis. Material and Methods: It is a retrospective, non-comparative observational Case series study done from March 2011 to August 2019. A total of 2165 patients were included in this study qualifying inclusion criterion. 8 to $10 \mathrm{~mm}$ Arruga's bone trephine was used to make osteum in lacrimal bone and passage in the nasal mucosa. The anterior margin of the lateral side of the remaining sac was sutured to the subcutaneous tissue of the medial side adjacent to the nasal osteotomy. Syringing with $1 \mathrm{ml}$ of $0.4 \mathrm{mg} / \mathrm{ml}$ MMC was done in the newly formed passage on the $5^{\text {th }}$ post-operative day. These patients were followed up for one year. The success criteria were symptomatic relief from epiphora subjectively. Objectively a patent nasolacrimal duct upon syringing and Nasal endoscopy. Results: 2136 (out of 2165) patients' eyes treated with this procedure showed resolution of epiphora with a success rate of $98.66 \%$. Conclusion: The current study suggest that DCR without flap making is an effective and easy procedure in the management of NLDO obstruction and flap making is a futile step in the procedure as it has no impact on the outcome.

Keywords: Nasolacrimal Duct obstruction (NLDO), Flapless external Dacryocystorhinostomy(DCR), Arruga's bone trephine, Mitomycin c syringing

Corresponding Author

Ravi Ranjan, Awadh Medicare, Bikramganj, Bihar, India.

Email: docdocravi4@gmail.com
How to Cite this Article

To Browse

Ranjan R, Rupam K, Kumar S. Change to win flapless external dacryocystorhinostomy (DCR). Trop J Ophthalmol Otolaryngol. 2020;5(8):224-230. Available From https://opthalmology.medresearch.in/index.php/jooo /article/view/169

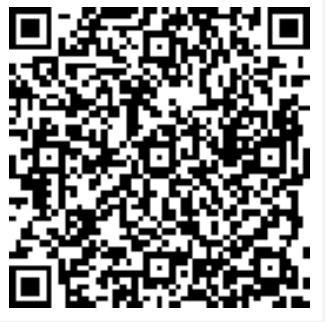

Manuscript Received 2020-10-22

Conflict of Interest No

(c) 2020 by Ravi Ranjan, Kumari Rupam, Sudhir Kumar and Published by Siddharth Health Research and Social Welfare Society. This is an Open Access article licensed under a Creative Commons Attribution 4.0 International License https://creativecommons.org/licenses/by/4.0/ unported [CC BY 4.0].

Accepted 2020-12-09 


\section{Introduction}

External Dacryocystorhinostomy (Ext. DCR) is the gold standard surgical technique used for the treatment of nasolacrimal duct obstruction (NLDO) which was popularised by Toti in 1904 and has changed little since then [1-2]. It required an external incision near the medial canthus of the eye to access the lacrimal sac and its fistulization into the nasal cavity. The success rate of Ext. DCR varies from 80 to $95 \%$ [3]. Fashioning a flap in DCR is a tedious and time-consuming process for many ophthalmic surgeons resulting in DCR ignorant ophthalmologists. A poorly fashioned flap usually results in procedure failure. It was shown in the present study that a comparable good result can be achieved without making tedious flaps and anastomosis. In addition to poorly fashioned flap, Common causes of DCR failure are osteogenesis and fibrogenesis at the osteotomy site. Mitomycin c (MMC), an alkalizing antibiotic that is an antiproliferative agent act by inhibiting DNA synthesis and interferes with RNA transcription and protein synthesis, was used as adjunctive. In this study $1 \mathrm{ml}$ of $0.4 \mathrm{mg} / \mathrm{ml}$ MMC was syringed in and around newly formed nasolacrimal passage on the 5th postoperative day through lower canaliculi [4].

\section{Material and Methods}

It is a retrospective, non-comparative observational case series study done from March 2011 to March 2019. 2182 patients underwent this surgery but only 2165 were included in this study as 17 patients were dropped due to lost follow up for 1 year. The age group ranged from 17 years to 72 years. 806 (37.2\%) patients were male while 1359 (62.8\%) patients were female. Right-sided NLD block was seen in $1271(58.7 \%)$ and the left side in 894 $(41.3 \%)$. Inclusion criteria were a diagnosed case of nasolacrimal duct blockage based on regurgitation of pus-like substance on pressure (ROPLAS) over medial canthus or syringing of the lacrimal passage. Exclusion criteria were patients with a history of nasal or orbital trauma, Patients with a severely deviated nasal septum, and atrophic rhinitis. Patients with uncontrolled diabetes, hypertension, coronary artery disease, and patients on anticoagulants. Routine test and complete hemogram including platelet count, Bleeding and clotting time, ELISA test for HIV, HbSAg, Liver, and kidney function test was done. Surgical fitness from the cardiologist was taken.

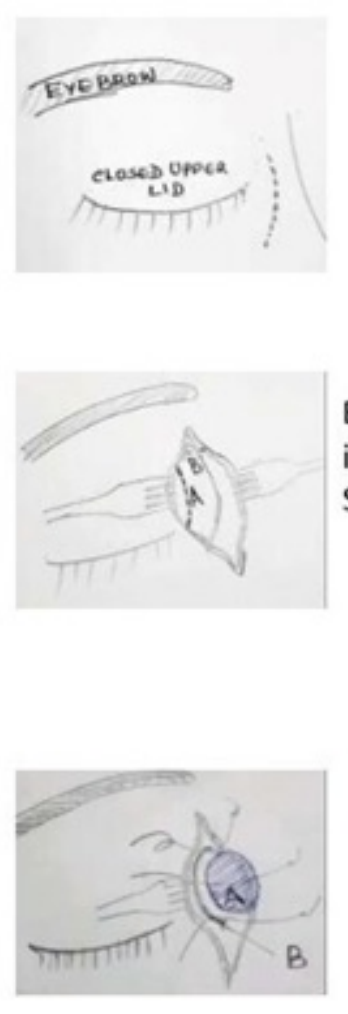

Dotted line showing skin incision

Medial palpebral ligament(MPL) and Ant. Lacrimal crest.

Exposer of Lacrimal Sac-(A) dotted lines shows incision for approx. Medial $3 / 4^{\text {th }}$ of the Lacrimal Sac removal (B) Lacrimal Sac

Lacrimal Sac after dissection-(A)Opening of common canaliculi (B) Lateral one fourth of Sac, the lateral part of the lacrimal sac remained as disc with punctum in its middle like a funnel

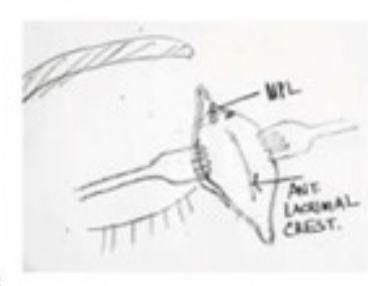

Suturing of Anterior margin of the lateral side of remaining sac was sutured to the sub cutaneous tissues adjacent to the osteotomy margin (A) Lateral one third of Sac.(B)Osteum in the nasal bone and mucosa.
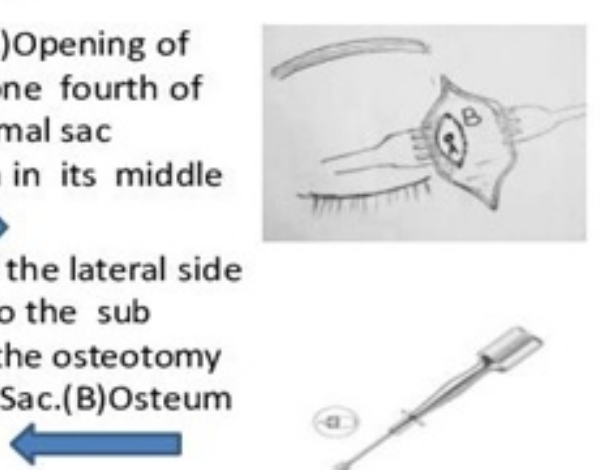

Fig 1-Steps of Flapless DCR Surgery. 
Surgical steps of Operation: $7 \mathrm{ml}-10 \mathrm{ml}$ of lignocaine $2 \%$ adrenalin 1:200000 was infiltrated around the lacrimal sac for anesthesia and hemostasis. Methylene blue was syringed in the sac for ease in recognizing the sac during surgery via the lower canaliculus. After anesthetizing the ipsilateral nasal mucosa by $4 \%$ lignocaine local anesthetic agent, anterior nasal packing was done with gauge soaked in $4 \%$ lignocaine with adrenalin.

Steps of flapless DCR (Figure 1)- A curvilinear skin incision $10-12 \mathrm{~mm}$ in length was made along anterior lacrimal crest up to $2-3 \mathrm{~mm}$ above the medial palpebral ligament (MPL) and 2-3 mm away from medial canthi to reduce the risk of scarring and avoid angular vessels. After separating the orbicularis muscle fibers, the MPL was divided or pushed upward depending on the size of the lacrimal sac.

The lacrimal sac was separated from the lacrimal fossa by blunt dissection. Roughly three fourth of the medial part of the lacrimal sac was removed leaving a small portion of the sac around the common canaliculus. So that the lateral part of the lacrimal sac remained as a disc with a punctum in its middle like a funnel (Figure 2).

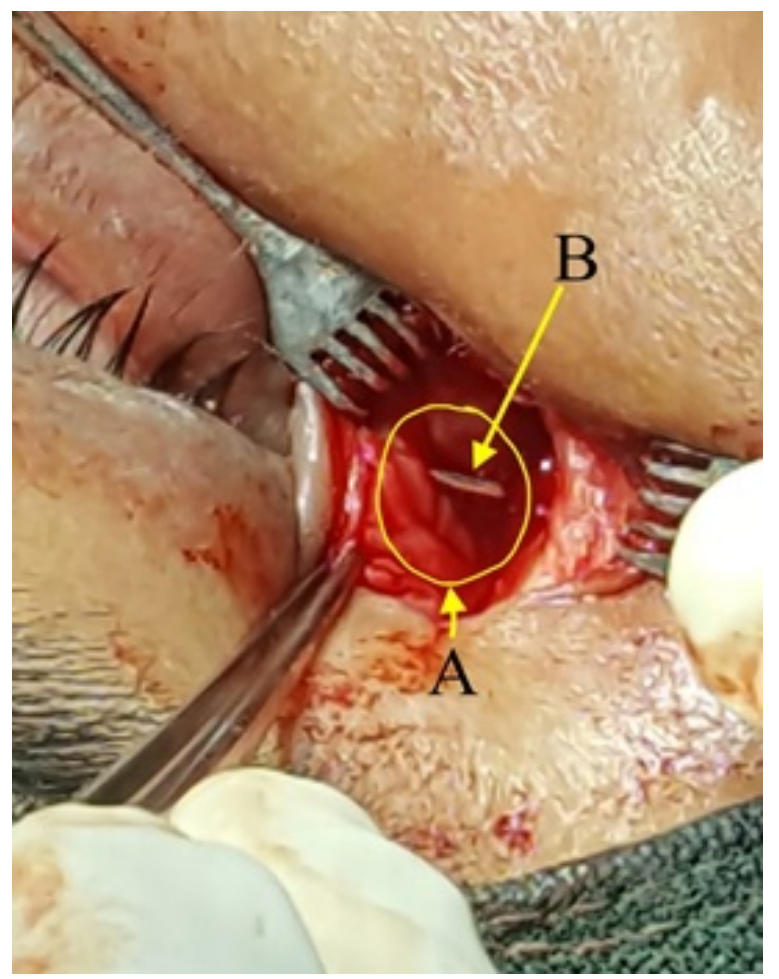

Fig-2- Showing remaining sac after medial 3/4th lacrimal sac removal. A. 1/4th Lacrimal sac after medial $3 / 4$ th of the sac removal $B$.
Tip of the bowman's probe coming out of common canaliculi opening. The $1 / 4$ th lateral part of the lacrimal sac remained as a disc with punctum in its middle like a funnel.

$10 \mathrm{~mm}$ Arruga's bone trephine was used to make osteum in lacrimal bone and passage in the nasal mucosa (Figure 3). The anterior margin of the lateral side of the remaining sac was sutured to the subcutaneous tissues adjacent to the osteotomy margin on the medial side to avoid sagging and blockage. Orbicularis muscle repositioned and MPL was repaired with an absorbable suture 5-0 Vicryl.

The skin was closed with interrupted 5-0 silk sutures. Systemic antibiotic, pain killer, and Xylometazoline Nasal drop for 5 days depending on external wound healing was given. Syringing with 1 $\mathrm{ml}$ of $0.4 \mathrm{mg} / \mathrm{ml} \mathrm{MMC}$ was done in the newly formed passage on the 5th postoperative day once in all cases. After 5 minutes MMC was washed by the syringing passage with $10 \mathrm{ml}$ of normal saline.

No major complication was encountered except hemorrhage, Punctum, and canalicular laceration, Sac loss, and Increased average surgical time. These patients were followed up for one year. Nasal Endoscopic examination for Osteum size changes was measured at one month, three months, six months, and one year and syringing with $1 \mathrm{ml}$ Moxifloxacine eye drop done just after endoscopy.

Osteum size shrinkage was marked in the first three months, after that it's nearly stable and found 3-5 $\mathrm{mm}$ oval/round in shape at one year (Figure 4). Surgical time ranged from 20 to 35 minutes.

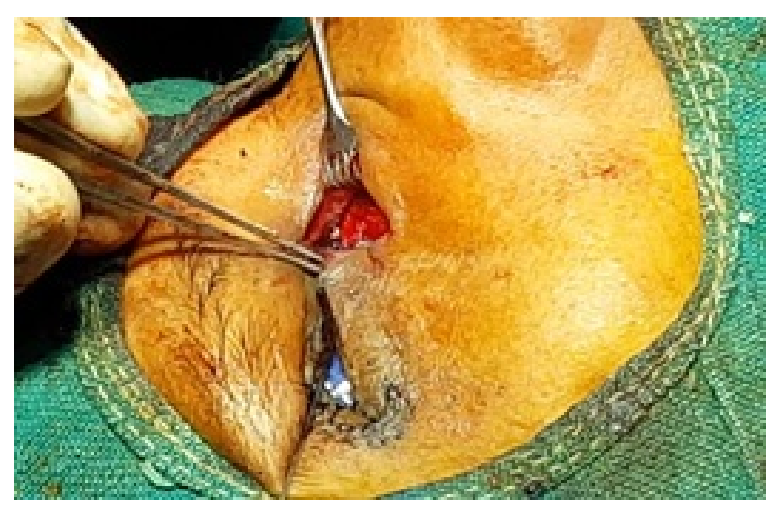

Fig-3: Osteum in the Lacrimal bone. 


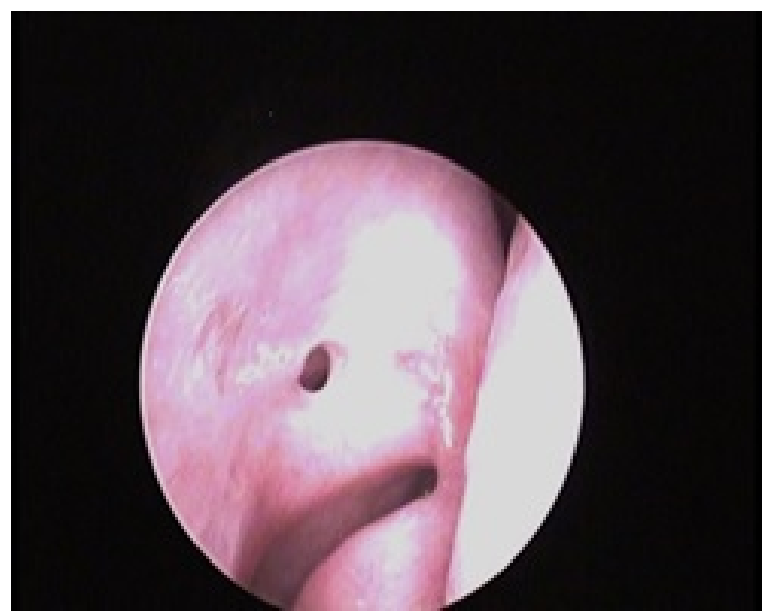

Fig-4: Nasal osteum seen by nasal endoscopy after one year.

Changes I made are- Medial part of the lacrimal sac was removed, Arruga's bone trephine is used to make osteum in the nasal bone adjacent to the lacrimal sac and nasal mucosa. The anterior margin of the lateral side of the remaining sac was sutured to the subcutaneous tissues adjacent to the osteotomy margin on the medial side. Mitomycin c is used on the 5th day for syringing in the newly formed passage.

Outcome assessment-All patients were followed-up on One week, One month, three months, six months, and one year postoperatively. At each visit, tearing was checked and a lacrimal syringing test was performed. The surgical outcome was assessed anatomically and functionally based on records from the last visit. Anatomical success was defined as a patent when no significant reflux on a syringing test. Functional success was defined as the absence of tearing assessed using Munk's score [5] Epiphora of grade 0 or 1 (no Epiphora or occasional Epiphora requiring dabbing less than twice a day) was considered as a success, whereas Epiphora from Risk factors of functional failure after external dacryocystorhinostomy grade two or more (Epiphora requiring dabbing twice and over) was defined as failure.

\section{Result}

Results were analyzed after the end of the study and 2136 (98.66) Patients were successful at end of the mean follow up period (12 months), $13(0.6 \%)$ patients complained of epiphora grade two or more (epiphora requiring dabbing twice and over) and sticky eye at end of mean follow up period
(12 months) despite successful syringing and patent newly formed nasal osteum and 16 (0.73\%) patients failed in syringing during the follow-up period. Thus in the present study Anatomical/ objective success $-2149 \quad(99.26 \%)$ and Functional/subjective success. Is $2136(98.66 \%)$.

\section{Discussion}

Epiphora /ROPLAS is a frequent symptom associated with acute or chronic dacryocystitis. The treatment consists of creating a fistula from the lacrimal sac to the nasal cavity. Personal communication with many ophthalmologists revealed that failure of the procedure and tedious flap making in DCR are the main cause of reluctance from this surgery. As a result, DCR is ignored by many eye surgeons and lacrimal surgery is increasingly being undertaken by Ear, Nose, and Throat (ENT) surgeons in the peripheral part of India. In an era where every specialty is widening its wings, the current scenario about losing our patients to ENT Surgeons. To overcome the problem and make the surgery easy to perform with successful results with a short learning curve, Authors conceptualize this no flap DCR technique.

Many experts opine that it's very easy to make flaps, but personal communications to many ophthalmologists revealed that it's not that much easy on the operation table for general/comprehensive ophthalmologists. In this study, females are found to be more prone to this disease than males. It may be due to the narrower lumen of the bony canal i.e. nasolacrimal canal while Heinonen associated it with nasal index $[8,7]$. An endocrine etiology has also been suggested by G. Pico. In a study by Eshragi et al, the incidence of dacryocystitis has been found more in a rural population attributed to poor hygiene. It might be due to delay in treatment, illiteracy, and poor hygiene $[7,8]$.

Mohamed Al-Taher A.A. suggested that DCR with no flap making is an effective and easy procedure in the management of NLDO and flap making is not a crucial step in the procedure as it has no impact on the outcome [9]. Inspired by the study of Mohamed Al-Taher A.A's Ext-DCR with no flap, High success rates of conventional Endonasal DCR which is without flaps and Result of Probing with MMC syringing in NLDO, Authors planned this maverick "external" DCR without flaps With $1 \mathrm{ml}$ of $0.4 \mathrm{mg} / \mathrm{ml}$ 
MMC syringing on 5 th postoperative days so that the antifibrotic property of MMC is utilized maximally as it is not diluted by bleeding from nasal mucosa and better coincides to early proliferative phase of wound healing which starts from 4 to 5 days of tissue injury.

After initial encouraging results, the current study performed more and more cases by this method. Hence, the technically difficult flap making and suturing flaps are omitted in this modified procedure. Here it has been postulated that the osteotomy done without flaps has much fewer instances of "adhesions" or "synechia" that may lead to the obstruction of the tract constructed during conventional Osteotomy procedure.

\section{Why Mitomycin c is used?}

The most frequent causes of DCR failure is osteotomy closure because of granulation and fibrotic tissue. Emine $A$ et al detected excessive granulation tissue at the operation site as the main reason for failure [10].

Tilakraj Singh et. al Mitomycin c can be used safely in human Sinonasal mucosa to prevent adhesion formation and to delay healing of intranasal antrostomy [11]. Deka et al from a study on the effect of MMC on ostium size concluded that MMC use leads to larger ostium size throughout the postoperative period [12]. Hence, it has been used as adjunctive therapy here.

\section{Why $0.4 \mathrm{mg} / \mathrm{ml}$ ?}

Currently, there are no definite guidelines on the dose and duration of MMC application in DCR surgery. It was found that the safest and most effective dose of MMC is between $0.2 \mathrm{mg} / \mathrm{ml}$ $0.4 \mathrm{mg} / \mathrm{ml}$. A single $5 \mathrm{~min}$ topical application has a measurable effect on cell proliferation and cellular morphology for up to $36 \mathrm{~h}$ [13]. Considering this view the current study had used $1 \mathrm{ml} 0.4 \mathrm{mg} / \mathrm{ml}$ here.

\section{Why on the 5th postoperative days?}

In the present study, syringing of $0.4 \mathrm{mg} / \mathrm{ml} \mathrm{MMC} \mathrm{in}$ the newly formed lacrimal passage on the 5th postoperative day, decreased the incidence of postoperative adhesion more significant because it is not diluted by bleeding from nasal mucosa and better coincides with to early proliferative phase which starts from 4th to 5th day of tissue injury (the stage of fibroblast migration and proliferation in the wound).
As there is no standardized classification of success and systematic clinical evaluation, the major problem lies in comparing the reported outcomes, as many authors only rely on patients' assessments, some use endoscopy to visualize the rhinostomy, and others examine the lacrimal drainage system with fluorescein dye testing. In this study complete success was considered when the tearing under normal conditions had been resolved, with no recurring infection and minimal or no reflex through the opposite canaliculus after lacrimal syringing.

Although the current study had visualized nasal osteum by a nasal endoscope (Figure 4 ) in the present study $13(0.6 \%)$ patients complained of epiphora and sticky eye at end of the mean followup period (12 months) despite successful syringing and patent newly formed nasal osteum. It was supposed this functional tearing. Authors compared different Studies reporting results of different ExtDCR Using MMC in the last 20 years (Table 1 ).

\section{Table-1: Studies reporting results of different} Ext-DCR.

\begin{tabular}{|c|c|c|c|c|c|}
\hline Author & Year & Success & $\begin{array}{l}\text { Sample } \\
\text { size }\end{array}$ & Difference & P-value \\
\hline $\begin{array}{l}\text { Cokkeser et al } \\
{[14]}\end{array}$ & 2000 & $89.8 \%$ & 79 & $\mid \begin{array}{l}8.8 \% ; 95 \% \text { CI: } 3.8 \text { to } \\
17.4\end{array}$ & $\mid \begin{array}{l}\mathrm{P}< \\
0.0001\end{array}$ \\
\hline $\begin{array}{l}\text { Ben Simon et } \\
\text { al [15] }\end{array}$ & 2005 & $70 \%$ & 176 & $\begin{array}{l}28.6 \% ; 95 \% \text { CI: } 22.2 \\
\text { to } 35.7\end{array}$ & $\mid \begin{array}{l}P< \\
0.0001\end{array}$ \\
\hline $\begin{array}{l}\text { Sharma et al } \\
{[16]}\end{array}$ & 2008 & $90.5 \%$ & 137 & $\mid \begin{array}{l}8.1 \% ; 95 \% \text { CI: } 4.1 \text { to } \\
14.1\end{array}$ & $\mid \begin{array}{l}\mathrm{P}< \\
0.0001\end{array}$ \\
\hline $\begin{array}{l}\text { Mikito et al } \\
{[17]}\end{array}$ & 2011 & $90.5 \%$ & 25 & $\begin{array}{l}8.1 \% ; 95 \% \text { CI: } 1.4 \text { to } \\
25.4\end{array}$ & $P=0.000$ \\
\hline $\begin{array}{l}\text { Karim et al } \\
{[18]}\end{array}$ & 2011 & $91 \%$ & 100 & $\begin{array}{l}7.6 \% ; 95 \% \text { CI: } 3.3 \text { to } \\
14.8\end{array}$ & $\begin{array}{l}P< \\
0.0001\end{array}$ \\
\hline $\begin{array}{l}\text { Dolman et al } \\
{[19]}\end{array}$ & 2003 & $90.2 \%$ & 153 & $\mid \begin{array}{l}8.4 \% ; 95 \% \text { CI: } 4.5 \text { to } \\
14.1\end{array}$ & $\begin{array}{l}\mathrm{P}< \\
0.0001\end{array}$ \\
\hline Zaidi et al [20] & 2011 & $100 \%$ & 25 & NA & NA \\
\hline Present study & 2019 & $98.60 \%$ & 2165 & $95 \%$ CI: $98.1-99.1 \%$ & \\
\hline
\end{tabular}

\section{Conclusion}

Hereby, The present study suggests that Ext. DCR without flap is easier to perform and may improve the success rate of Ext. DCR. Ext. DCR with success rates as high as $98.6 \%$ in the second year, comparable to the available result of any external DCR and endoscopic DCR techniques. The success rate of the current study is significantly better than the previously published reports despite the large sample size (2165). The success rate in this study was $98.6 \%$ (95\% CI: $98.1-99.1 \%$ ). 
The success rate among published research varies from $80 \%$ to $95 \%$ and the sample size of the studies published also ranged from 19 to 176 . The current study conclude the flapless method is easy to perform with the reliable and comparative result.

\section{What does the study add to the existing knowledge?}

This result supports the flapless technique because it's less cumbersome and easy to perform with a comparable result, lower learning curve, Needs no costly special instruments, Can be used for mass surgeries in camps. Repeat/failed DCR can also be done by this method because getting sufficient flaps for mucosal anastomosis is too difficult.

\section{Author's contribution}

Dr. Ravi Ranjan: Concept

Dr. Kumari Rupam: Study design

Dr. Sudhir Kumar: Manuscript preparation

\section{Reference}

01. Toti A. Nuovo metodo conservatore di cura radicale dellesuppurazioni croniche del sacco lacrimale (dacriocistorinostomia). Clin Mod Fir. 1904; 10;385-387.

[Crossref]

02. Dupuy-Dutemps L, Bourguet J. Procede plastique de dacryocystorhinostomie et ses resultats. Ann Ocul. 1921;158;241-261.

[Crossref]

03. Pei-Yuan Su. Comparison of endoscopic and external dacryocystorhinostomy for treatment of primary acquired nasolacrimal duct obstruction. Taiwan J Ophthalmol. 2018;8(1)19-23.

doi: 10.4103/tjo.tjo_10_18 [Crossref]

04. Ranjan R. There Is No Use Crying Over Failed Dacryocystorhinostomy (DCR)- The Management of Unsuccessful Lacrimal Surgery Oculoplastics, Lacrimal System and Orbit. FPTH-14-8/WOC, Tokyo. 2014.

[Crossref]

05. Munk PL, Lin DT, Morris DC. Epiphora- treatment by means of dacryocystoplasty with balloon dilation of the nasolacrimal drainage apparatus. Radiol. 1990;177(3)687-690.

doi: 10.1148/radiology.177.3.2243969 [Crossref]
06. Shigeta K, Takegoshi H, Kikuchi S. Sex and age differences in the bony nasolacrimal canal- An anatomical study. Arch Ophthalmol. 2007;125(12)1677-1681.

doi: $\quad 10.1001 /$ archopht.125.12.1677 [Crossref]

07. Bartley GB. Acquired lacrimal drainage obstruction- An etiologic classification system, case reports, and a review of the literature- Part 1. Ophthal Plast Reconstr Surg. 1992;8(4)237242.

[Crossref]

08. Eshraghi B, Abdi P, Akbari M, Fard MA. Micro biologic spectrum of acute and chronic dacry ocystitis. Int J Ophthalmol. 2014;7(5)864-7. doi: 10.3980/j.issn.2222-3959.2014.05.23 [Crossref]

09. Mohamed Al-Taher AA. Flapless external dacryocystorhinostomy (DCR)- do flaps really matter?. AAMJ. 2012;10(3).

[Crossref]

10. Akcay E, Yuksel N, Ozen U. Revision External Dacryocystorhinostomy Results After a Failed Dacryocystorhinostomy Surgery. Ophthalmol Ther. 2016;5(1)75-80.

doi: $\quad 10.1007 / \mathrm{s} 40123-016-0048-4 \quad$ [Crossref]

11. Singh $T$, Lade $H$, Natesh V. Role of Mitomycin-C in Prevention of Post-Operative Adhesions After Endoscopic Sinus Surgery- A Prospective Study. Indian J Otolaryngol Head Neck Surg. $2011 ; 63(3) 249-254$.

doi: $\quad 10.1007 / \mathrm{s} 12070-011-0145-6 \quad$ [Crossref]

12. Deka A, Bhattacharjee K, Bhuyan SK, Barua CK, Bhattacharjee $H$, Khaund $G$. effect of mitomycin $C$ on ostium in dacryocystorhinostomy. Clin Experiment Ophthalmol. 2006;34(6)557-561. doi: $10.1111 / j .1442-9071.2006 .01265 . x$ [Crossref]

13. Lee JJ, Park KH, Youn DH. The effect of low-and high-dose adjunctive mitomycin $\mathrm{C}$ in trabeculectomy. Korean J Ophthalmol. $1996 ; 10(1) 42-47$. doi: $10.3341 /$ kjo.1996.10.1.42 [Crossref]

14. Cokkeser Y, Evereklioglu C, Er H. Comparative externalversus endoscopic dacryocystorhinosto my- result in 115 patients (130 eyes). Otolaryn gol Head Neck Surg.2000;123(4)488-91. doi: $10.1067 / \mathrm{mhn} .2000 .105470$ [Crossref] 
15. Ben Simon GJ, Joseph J, Lee S. External versus endoscopic dacryocystorhinostomy for acquired nasolacrimal duct obstruction in a tertiary referral center. Ophthalmology. $2005 ; 112(8) 1463-1468$.

doi: $10.1016 /$ j.ophtha.2005.03.015 [Crossref]

16. Sharma BR. Non-endoscopic endonasal dacryocystorhinostomy versus external dacryocystorhinostomy. Kathmandu Univ Med J. 2008;6(24)437-442.

doi: $10.3126 /$ kumj.v6i4.1731 [Crossref]

17. Akaishi PM, Mano JB, Pereira IC, Cruz AA. Functional and cosmetic results of a lower eyelid crease approach for external dacryocystorhinostomy. Arq Bras Oftalmol. $2011 ; 74(4) 283-285$.

doi: $10.1590 / s 0004-27492011000400011$ [Crossref]
18. Karim R, Ghabrial R, Lynch TF, Tang B. A comparison of external and endoscopic endonasal dacryocystorhinostomy for acquired nasolacrimal duct obstruction. Clin Ophthalmol. 2011;5;979-989.

doi: 10.2147/OPTH.S19455 [Crossref]

19. Dolman PJ. Comparison of external dacryocystorhinostomy with nonlaser endonasal dacryocystorhinostomy. Ophthalmology. $2003 ; 110(1) 78-84$.

doi: $10.1016 / s 0161-6420(02) 01452-5$ [Crossref]

20. Zaidi FH, Symanski S, Olvera JM. Clinical trial of endoscopic vs external dacryocystorhinostomy for partial nasolacrimal duct obstruction. Eye. 2011;25(9)1219-1224.

doi: 10.1038/eye.2011.77 [Crossref] 